4. Олифер В., Олифер Н. Новые технологии в обучении. С.Пб.: БХВСанкт-Петербург, 2000.

5. Сахарусова Т.А. «Использование информационных технологий для повышения уровня мотивации всех участников образовательного процесса» 2008 г.

6. Титоренко Г.А. Современные информационные технологии. М.: ЮНИТИ, 1999.

7. Шутенко, А.В. Методы проведения учебных занятий с использованием средств информационных и коммуникационных технологий / А.В. Шутенко [Электронный документ].- (http://pedsovet.su/publ/26-1-0-841). 05.04.2010.

8. Ефимов П. П., Ефимова И. О. Интерактивные методы обучения основа инновационных педагогических технологий [Текст] // Инновационные педагогические технологии: материалы Междунар. науч. конф. (г. Казань, октябрь 2014 г.). — Казань: Бук, 2014. — С. 286-290.

Статья отправлена: 28.02.2017 г.

(C) Галактионова Н.П.

ЦИТ: ua117-020

DOI: 10.21893/2415-7538.2016-05-1-020

УДК 005.336.2:81'243]-057.875(61:378.4)

СПЕЦИФІКА РОЗВИТКУ ІНШОМОВНОЇ КОМПЕТЕНТНОСТІ СТУДЕНТІВ В УМОВАХ МЕДИЧНОГО УНІВЕРСИТЕТУ

Запорізький державний медичний університет, м. Запоріжжя

Victoria V.Z.

THE SPECIFIC FEATURES OF THE DEVELOPMENT OF THE STUDENTS` FOREIGN LANGUAGE COMPETENCE AT A MEDICAL UNIVERSITY

У статті проаналізовано специфбіку розвитку іншомовної компетентності студентів медичних університетів. Обтрунтовано педагогічний супровід розвитку іншомовної компетентності майбутніх лікарів. Визначено роль неперервного навчання іноземним мовам для студентівмедиків щодо підвищення їхньої конкурентоспроможності в умовах сучасного ринку пращі.

Ключові слова: іншомовна компетентність, іншомовна підготовка, педагогічний супровід, студенти, університет.

Specific features of the development of medical university students' foreign language competence are analyzed in this article. The pedagogical support of the development process of future doctors ' foreign language competence has been grounded. The role of continuous study of foreign languages to improve the competiveness at the modern labour market is determined.

Key words: foreign language competence, foreign language training, pedagogical support, students, University.

Постановка проблеми. Модернізація державної освітньої політики в 
умовах інтенсивного розвитку співпраці 3 іншими країнами зумовлює актуалізацію проблем підвищення якості підготовки фахівців, що передбачає сформованість у них здатності до виконання професійної діяльності в умовах іншомовного середовища. Оновлення змісту іншомовної освіти фахівців в нашій країні відповідає вимогам Загальноєвропейських рекомендацій з мовної освіти: вивчення, викладання, оцінювання [1].

Вища медична освіта нашої країни зазнає змін відповідно до процесів європейської інтеграції, що підтримуються урядом України та Міністерством освіти і науки. Навчання іноземній мові було й залишається невід'ємною складовою процесу формування сучасного лікаря. Щодо значущості виконання соціального замовлення свідчить той факт, що показник рівня володіння іноземною мовою включений у кваліфікаційну характеристику випускника медичного університету.

Актуальність зазначеної проблеми посилюється виявленими в процесі дослідження протиріччям між об'єктивною потребою суспільства в лікарях i медичних працівниках, здатних тісно співпрацювати 3 закордонними колегами та реальним станом готовності сучасних лікарів до іншомовної професійної комунікації.

Аналіз останніх досліджень і публікацій. Загальні питання професійної підготовки й змісту професійної освіти, різнотипні моделі формування фахівців досліджували А. Алексюк, В. Галузинський, Р. Гуревич, М. Свтух, І. Зязюн, Т. Сущенко та ін.

Проблемою формування іншомовної компетентності займалися такі зарубіжні науковці як І. Бім, М. Бірам, Н. Гез, Е. Зеєр, Р. Мільруд, В. Сафонова, М. Свейн, Д. Хаймс та ін. Проблемі підготовки майбутніх фахівців до професійного іншомовного спілкування присвячено праці вітчизняних дослідників І. Бахова, О. Тарнопольського, О. Хоменка та ін.

Розвиток іншомовної компетентності студентів в умовах вищої школи досліджували Д. Демченко, С. Ісаєнко, О. Кісельова, І. Секрет. Однак, аналіз праць зазначених науковців не дає цілісного уявлення про специфіку розвитку іншомовної компетентності у студентів медичних університетів.

Отже, здійснений теоретичний аналіз педагогічних праць i актуальних досліджень дозволив відзначити, що вітчизняний $\mathrm{i}$ зарубіжний досвід засвідчують пошук нових концептуальних підходів до структурування i прогнозування навчальних систем, які надавали 6 пріоритет психологопедагогічному фактору в процесі розроблення ефективних програм навчання студентів-медиків англійської мови професійного спрямування. У цьому відношенні, як ми вважаємо, великі потенційні можливості закладено в застосуванні педагогічного супроводу навчальної діяльності студентів 3 оволодіння іншомовною компетентністю.

Мета статті - проаналізувати специфіку розвитку іншомовної компетентності майбутніх лікарів в умовах навчання у медичному університеті.

Виклад основного матеріалу. У новій редакції Закону України «Про вищу освіту» у ст. 1 компетентність трактується як «динамічна комбінація знань, вмінь і практичних навичок, способів мислення, професійних, світоглядних i 
громадянських якостей, морально-етичних цінностей, яка визначає здатність особи успішно здійснювати професійну та подальшу навчальну діяльність і $\epsilon$ результатом навчання на певному рівні вищої освіти» [3]. Зауважимо, що у цьому визначені наголошено на таку властивість особистості, як здатність успішно виконувати професійну (або навчальну) діяльність.

У сучасних педагогічних дослідженнях 3 теорії і методики професійної освіти вітчизняні науковці Д. Демченко [1], С. Ісаєнко [4], О. Кісильова [5], I. Секрет [6] поняття іншомовної компетентності фахівців різних галузей розуміють як професійно значущу якість особистості представника певної професії, системно-ціннісне новоутворення, що забезпечує використання іншомовної професійної інформації (міжнародних документів, професійної термінології тощо), іiі використання в професійній діяльності (наприклад, у безпосередніх контактах 3 іноземними колегами) i «здатність здійснювати професійну діяльність в міжнародному професійному середовищі» [1, с. 7].

Для нашого дослідження цікавим $є$ аналіз діяльності вищих медичних навчальних закладів з організації процесу розвитку іншомовної компетентності студентів-медиків. Відзначимо, що іншомовна підготовка студентів-медиків здійснюється на основі традиційних підходів, які є пріоритетними в практиці вищої школи. Інформативний характер цих традиційних підходів фактично виключає можливість врахування у навчальному процесі ціннісних орієнтацій студента як дорослої людини, iii досвіду, реальних потреб і можливостей. Вважаємо, що оскільки інформативні моделі навчання орієнтовані на знання, вміння та навички, що стають метою навчального процесу, то головним завданням студента під час навчання є сприйняття дидактичної інформації.

Слід відмітити, що забезпечити відповідне сучасним вимогам вивчення іноземної мови студентами медичних спеціальностей тільки на аудиторних заняттях в системі вищої освіти неможливо. Неперервність навчання майбутніх лікарів як професіоналів, стає єдиним можливим шляхом вирішування складних завдань економічного, суспільно-політичного, соціального i культурного розвитку держави.

3 нашої точки зору, специфіка розвитку іншомовної компетентності студентів медичного університету полягає в тому, що необхідно створити системний педагогічний супровід навчальної діяльності майбутніх лікарів. Метою такого супроводу $\epsilon$ вдосконалення іншомовної компетентності як складової професіоналізму сучасних медиків.

Педагогічний супровід розвитку іншомовної компетентності студентів медичного університету ми розуміємо як науково-методичне забезпечення неперервного навчання іноземним мовам. До складу зазначеного супроводу входить концепція, модульна організація навчального процесу та рекомендації студентам з виконання самостійної роботи.

Відзначимо, що система взаємодії викладача зі студентами під час педагогічного супроводу передбачає не тільки аудиторну, а ще й дистанційну форми навчання, а саме: активне застосування діалогічних методів (дискусій), проблемний підхід до побудови всіх аспектів навчального процесу, розроблення творчих проектів, застосування дидактичних i рольових ігор, 
використання інформаційних технологій навчання.

У межах педагогічного супроводу, як зазначає українська вчена Л. Сущенко, завдання для самостійної роботи студентів слід розробляти відповідно до таких рівнів пізнавальної активності: 1) репродуктивний (характеризується здатністю студентів діяти за аналогією, за відомими алгоритмами); 2) евристичний (характеризується тим, що навчальна діяльність студентів спрямована на зображення нового підходу до вирішення завдання й передбачає використання аналітичних навичок, моделювання професійних ситуацій); 3) креативний (характеризується тим, що вирішення проблеми не обмежується лише евристичними прийомами, а постає самостійною проблемою, призводить до теоретичного відкриття або до постановки нової проблеми) [7].

Таким чином, результат навчально-пізнавальної діяльності студентів медичних університетів в процесі педагогічного супроводу розвитку іншомовної компетентності, полягає в наступному: у студентів виникає готовність до оволодіння системою знань, норм i цінностей професійного іншомовного середовища; підвищується мотивація студентів до опанування іноземною мовою; виникає розуміння перспективи щодо іiі застосування у майбутній професійній діяльності.

Відзначимо, що в процесі педагогічного супроводу у викладача повинна бути опора на мотивацію студентів до вивчення іноземної мови. Така мотивація, на нашу думку, спрямовує майбутню професійну діяльність.

Отже, вважаємо, що застосування педагогічного супроводу розвитку іншомовної компетентності студентів-медиків призведе до підвищення їхньої конкурентоспроможності як лікарів на вітчизняному і міжнародному ринках праці. Доцільним є продовження терміну вивчення іноземних мов впродовж усього періоду навчання в медичному університеті з огляду на їхнє значення у сучасному суспільстві.

Висновки. Таким чином, здійснений аналіз наукової літератури, власний досвід викладання іноземної мови в медичному університеті дозволяє стверджувати, що специфіка розвитку іншомовної компетентності майбутніх лікарів, визначається неперервністю процесу вивчення студентами іноземної мови.

Проведене нами дослідження не претендує на всебічне розв'язання проблеми аналізу специфіки розвитку іншомовної компетентності студентів медичних університетів. В перспективі вбачаємо вивчення психологопедагогічних умов іншомовної підготовки майбутніх лікарів.

Література

1. Демченко Д. І. Формування професійної іншомовної компетентності майбутніх юристів у фаховій підготовці : автореф. дис. ... канд. пед. наук : 13.00.04 / Діна Ісхаківна Демченко. - Харків, 2010. - 21 с.

2. Загальноєвропейські Рекомендації 3 мовної освіти: вивчення, викладання, оцінювання / [ ред. С. Ю. Ніколаєва]. - Київ : Ленвіт, 2003. - 273 с.

3. Закон України «Про вищу освіту» від 01.07.2014 № 1556-VII 
[Електронний ресурс] // Відомості Верховної Ради України. - 2014. - № 37-38. - Ст.2004. - Режим доступу: http://zakon2.rada.gov.ua/laws/show/1556-18.

4. Ісаєнко С. А. Усвідомлене опанування іноземною мовою як один 3 чинників активізації навчальної діяльності студента немовного ВНЗ / С. А. Ісаєнко // Проблеми освіти. - 2012. - № 70 (Ч. 2). - С. 23 -238.

5. Кісельова О. Г. Методика навчання медичної термінології майбутніх лікарів / О. Г. Кісельова // Педагогічний процес: теорія і практика. - 2013. - № 4. - C. 62-68.

6. Секрет I. В. Педагогічні умови формування іншомовної професійної компетентності у вищому технічному навчальному закладі в умовах дистанційної освіти / І. В. Секрет// Вісник ЛНУ імені Тараса Шевченка. - 2012. - № 15 (250), Ч. III. - C. 90-102.

7. Сущенко Л. О. Науково-педагогічний супровід професійного зростання освітян: теорія і практика [Текст] : монографія / Л. О. Сущенко ; Нац. пед. ун-т ім. М. П. Драгоманова. - Запоріжжя : Класич. приват. ун-т, 2011. - 147 с.

\section{ЦИТ: ua117-031}

DOI: 10.21893/2415-7538.2016-05-1-031

УДК 515.2:536.3:664.8

\section{КОНТРОЛЬНІ ЗАВДАННЯ У ФОРМУВАННІ ПРОФЕСІЙНИХ ЗНАНЬ \\ ТА НАВИЧОК 3 ДИСЦИПЛІНИ «ІНЖЕНЕРНА ГРАФІКА» \\ Національний технічний університет Украӥни «Київський політехнічний інститут імені Ігоря Сікорського», м. Київ, проспект Перемоги, 37,03056}

Kolomiyets N.Y., Dopira A.G., Golova O. A.

\section{CONTROL TASKS IN FORMATION PROFESSIONAL KNOWLEDGE AND SKILLS ON DISCIPLINE "ENGINEERING GRAPHICS"}

National Technical University of Ukraine "Kyiv Polytechnic Institute named Igor Sikorsky", m. Kyiv, Victory Avenue, 37,03056

Анотація. В статті проведено огляд контрольних завдань, які сприяють закріпленню, перевіриі та систематизаиії знань та навичок студентів вищих навчальних закладів у питаннях створення конструкторської документації; обтрунтовується доцільність проведення контрольних заходів, розглядається методика використання.

Ключові слова: навчальний прочес, освіта, навчання, контроль знань, професійні навички.

Abstract. The article is a review of control tasks that contribute to the consolidation, verification and systematization of knowledge and skills of university students in the creation of the design documentation; the expediency of control measures, the technique used.

Key words: educational process, education, training and control of knowledge, skills.

Вступ. Наша молодь - майбутне України. ІІЇ інноваційна діяльність і молодіжна наполегливість у пошуку методів розв'язання наукових, технічних та 